\title{
An Overview on the Associations between Health Behaviors and Brain Health in Children and Adolescents with Special Reference to Diet Quality
}

\author{
Sehrish Naveed ${ }^{1, *(\mathbb{D})}$, Timo Lakka ${ }^{1,2,3}$ and Eero A. Haapala ${ }^{1,4}$ \\ 1 Physiology, Institute of Biomedicine, University of Eastern Finland, Kuopio Campus, 70211 Kuopio, Finland; \\ Timo.Lakka@uef.fi (T.L.); Eero.a.haapala@jyu.fi (E.A.H.) \\ 2 Department of Clinical Physiology and Nuclear Medicine, Kuopio University Hospital and University of \\ Eastern Finland, 70211 Kuopio, Finland \\ 3 Kuopio Research Institute of Exercise Medicine, 70100 Kuopio, Finland \\ 4 Faculty of Sport and Health Sciences, University of Jyväskylä, 40014 Jyväskylä, Finland \\ * Correspondence: sehrisn@uef.fi
}

Received: 13 January 2020; Accepted: 30 January 2020; Published: 4 February 2020

\begin{abstract}
Unhealthy diet has been associated with overweight, obesity, increased cardiometabolic risk, and recently, to impaired cognition and academic performance. The aim of this review is to provide an overview of the associations between health behaviors and cognition and academic achievement in children and adolescents under 18 years of age with a special reference to diet quality. Dietary patterns with a low consumption of fish, fruits, and vegetables, and high in fast food, sausages, and soft drinks have been linked to poor cognition and academic achievement. The studies on the associations between the high intake of saturated fat and red meat and low intake of fiber and high-fiber grain products with cognition are limited. The available evidence and physiological mechanisms suggest that diet may have direct, indirect, and synergistic effects on brain and cognition with physical activity, sedentary behaviors, cardiometabolic health, and sleep, but the associations have been modest. Therefore, integrating a healthy diet, physically active lifestyle, and adequate sleep may provide optimal circumstances for brain development and learning. We conclude that most of the existing literature is contained in cross-sectional studies, which therefore highlights the need for longitudinal and intervention studies on the effects of diet, physical activity, sedentary behavior, and sleep on cognition and academic performance.
\end{abstract}

Keywords: health behaviors; lifestyles; diet quality; nutrition; brain; brain health; cognition; learning; children; adolescents

\section{Introduction}

Poor nutrition may impair rapidly developing brain and cognitive functions, and low quality diets may also deteriorate the academic achievement of children [1]. Poor cognition and academic achievement in childhood have been linked to an increased risk of adulthood obesity, unemployment, and low socioeconomic positioning in adulthood, suggesting that it is important to identify possibilities to support brain development, cognition, and academic achievement in childhood [2-4]. Given that proper nutrition is important for brain development, cognition, and academic achievement, recent evidence concerning the dietary patterns of children is alarming. A child's diet typically includes a high intake of saturated fat and sucrose, a high consumption of fast foods, and a low consumption of vegetables [5-9].

There is also increasing evidence that children and adolescents grow physically inactive and spend most of their waking hours being sedentary [10]. It has been estimated that approximately 
half of children achieve the recommended 60 min of moderate-to-vigorous physical activity and the proportion decreases as age increases [11,12]. Some studies have also provided evidence that sleep duration has decreased during the past decades in children and adolescents $[13,14]$. Increased use of electronic devices (e.g., computers and mobile phones) in the evening may also compromise sleep [15].

The prevalence of pediatric overweight has also increased dramatically during the past few decades. Approximately $18.5 \%$ of American children and adolescents are overweight or obese [16]. In Europe, the prevalence of overweight or obese children, combined, varies from approximately 8\%-13\% in Estonia, France, and Netherlands to $26-32 \%$ in Greece, Italy, and Portugal $[17,18]$. In Finland, it has been estimated that $10 \%$ of boys and $18 \%$ of girls aged five and $20 \%$ of children aged $7-13$ are overweight or obese $[19,20]$. Moreover, a recent study in a population sample of Finnish children aged 2-16 years reported that $26 \%$ of boys and $16 \%$ of girls were overweight [21].

Previous studies have provided some evidence that a lower intake of polyunsaturated fatty acids (PUFAs) [22,23], a higher intake of saturated fat [24,25], a lower consumption of vegetables and fish [22,23], and a poor adherence to the Mediterranean diet, the Dietary Approaches to Stop Hypertension (DASH) diet, and the Nordic diet [26-29] may increase the risk of dementia and Alzheimer's disease among adults and older adults. Similarly, increased cardiometabolic risk has been linked to an increased risk of dementia in older adults [30]. Furthermore, a multidomain intervention including diet, exercise, and cognitive training has been found to improve cognitive functions in elderly individuals at an increased risk of dementia [31]. While a proper diet, sufficient levels of physical activity, and an adequate amount of sleep are essential for normal brain and cognitive development and subsequent academic performance [13,32,33], less is known about the associations of diet, physical activity, and sleep with brain function, cognition, and learning in children and adolescents.

Due to the increased emphasis on education and learning, evidence on the associations between diet and cognition and academic achievement among children and adolescents would provide valuable information for schools and parents to implement actions to support learning and academic achievement. Therefore, the aim of this review is to provide an overview on the associations of health behaviors, with special reference to diet quality, with brain structure and function, cognition, and academic achievement in children and adolescents under 18 years of age. This literature review is based on the studies conducted from 1998 to 2019 on the associations of health behaviors, including dietary intakes, physical activity, sedentary activities, and sleep with cognition and academic achievements in children and adolescents aged less than 18.

\section{Results}

\subsection{Health Behaviors and the Brain}

Health-related behaviors such as poor diet quality, physical inactivity, and decreased sleep, and the resulting increased cardiometabolic risk factors, overweight, and obesity, have been related to impaired cognition in children and adolescents. These health-related behaviors are recognized as modifiable risk factors [34]. Here, we elaborate on the existing evidence on the possible effects of physical activity, sedentary behavior, sleep, and diet quality on cognition and the synergistic effects of these lifestyle-related factors on the developing brain and on cognition.

\subsubsection{Physical Activity and the Brain}

Physical activity has been an integral part of humans' life and physically active and fit was the basic phenotype of humans for thousands of years [35]. Adequate, safe, and healthy diets may support the levels of physical activity in children and adolescents, while undernourishment may prevent adequate and normal levels of physical activity [36,37]. Physical activity has been associated with increased brain functioning by increasing the blood flow, boosting glucose, and lipid metabolism [38-40], and increasing the level of several growth factors such as brain derived neurotrophic factor (BDNF) [39]. Physical activity have also been associated with increasing grey matter volumes in the frontal and 
hippocampal regions of the brain $[40,41]$. All these effects of physical activity on brain have been related to improved cognitive functioning [42]. Higher levels physical activity has been linked to better brain functions and structures, cognitive functions, and academic achievement in children and adolescents in some, but not all, cross-sectional studies [33]. While some studies have found an association between objectively measured physical activity, cognition, and academic achievement [43-45], others have shown weak, if any, associations of objectively measured physical activity with cognition and academic achievement in children [46-49]

Exercise interventions also have provided some evidence that increasing after-school or classroom physical activity improve cognitive functions and academic achievement in children [50-52]. Increasing physical exercise levels has been related to structural changes in the brain and subsequently with better cognition and academic achievement in comparison to sedentary individuals [33,53]. Similarly, it has been demonstrated that, compared to sedentary fellows, the children involved in regular aerobic exercise performed better on verbal, perceptual, and arithmetic tests [54-56]. However, not all intervention studies have found improved cognitive functions [54] or academic achievement [57]. These results may suggest that physical activity may have weak effects on cognition in mainstream children, but a stronger effect on brain and cognition among children with attention deficit/hyperactivity disorder (ADHD) [58,59], poor academic performance [60], low fitness levels, or who are overweight or obese [61-63]. Furthermore, it is possible that not all exercise programs are equally effective in order to improve cognitive functions and academic achievement [64].

Coordinative exercise has been found to be more effective than cardiovascular exercise to improve cognitive functions in some studies [37,65]. Furthermore, the effects of physical activity on cognition and academic performance may be context specific; while Mullender-Wijsma et al. [54] found a positive effect of an active academic lessons on academic performance, the same group observed no effect on executive functions among the same children [54]. Some studies have found a direct association of motor skills, but not cardiorespiratory fitness, with academic performance and cognition in children [66,67]. Some evidence also suggests that exercise training augments the effects of DHA on the brain [68]. Furthermore, exercise training has been shown to counteract the adverse effects of unhealthy diet on the brain [68].

\subsubsection{Sedentary Behavior and the Brain}

Sedentary behavior refers to behavior in a sitting or reclined position with low energy expenditure [69]. High levels of screen time, and especially a longer time spent watching television, has been associated with poorer cognitive functions and academic achievement in children and adolescents [70-72]. In contrast, some sedentary behaviors, such as reading and drawing, may improve cognitive functions and academic performance in children [73]. These differences in the direction of the associations of different types of sedentary behaviors with cognition and academic achievement may explain the weak and inconsistent associations between objectively measured sedentary time and cognitive functions in youth $[44,46,47,74]$. The inverse associations of television watching with cognition and academic performance may also be partly due to unhealthy snacking while watching television [75]. Sedentary behavior and particularly television watching and screen-time have been associated with the increased consumption of energy dense food and a lower consumption of fruits and vegetables [75].

\subsubsection{Overweight, Obesity, Cardiometabolic Risk and the Brain}

Unhealthy diet has been associated with overweight and obesity and increased cardiometabolic risk in children and adolescents [76,77]. Overweight and obesity have been related to poorer cognitive functions [66,78-80] and academic achievement [81,82] in children and adolescents. Furthermore, insulin resistance [83] and increased cardiometabolic risk has been linked to decreased hippocampal volume, reduced white matter integrity, frontal lobe white matter volumes in adolescents [84,85], 
and to poorer cognitive functions in children [86]. Some evidence also suggests an inverse association between systemic inflammation and academic performance in adolescents [87].

Cross-sectional studies have found the inverse association between weight status and cognitive performance, especially in tasks involving attention and comprehension [88,89]. Another study comparing overweight, normal weight, and sport trained individuals demonstrated that normal weight individuals had better cognitive functions than overweight individuals [90]. However, the sport trained individuals were better in cognitive performance than normal weight individuals, illustrating that higher cardiorespiratory fitness may play a crucial role in cognitive health [90]. A systematic review of longitudinal studies show inconsistent associations of overweight and obesity with cognition, except in adolescent girls [91]. However, a recent longitudinal study found no causal relationship between childhood obesity and cognitive performance [92]. Nevertheless, the results of one study suggested a positive relationship between body adiposity and academic achievement in children living in India, suggesting that excess energy intake may be better for brain development and learning than undernourishment [78].

\subsubsection{Sleep and the Brain}

Sleep is essential for brain development, learning, and memory [93]. Existing studies have directly linked sleep duration and quality with all three subcomponents of executive function, i.e., working memory, inhibitory control, and cognitive flexibility. A meta-analysis found children's age as a substantial moderator of the association of sleep duration, quality, and daytime sleepiness with children's school performance; with younger children showing stronger positive relationship than older children [94]. It is also believed that sleep restriction impairs complex cognitive functions more than the general cognitive abilities, such as language and knowledge in children $[95,96]$.

Partial sleep deprivation is associated with impaired working memory in adolescents [97-99]. Current evidence demonstrates that decreasing sleep by an hour for four nights deteriorates the working memory of school-aged children [100]. However, increasing sleep duration and quality improved the working memory of adolescents [96]. Some evidence indicates that a short sleeping duration is linked to poorer cognition and academic performance in children and youth [64,101]. Short sleep duration of less than $10 \mathrm{~h}$ in early life is associated with impaired task performance in later ages as well—even with normalized sleep duration one year before cognitive evaluation [102].

Decreased and disturbed sleep patterns are associated with impaired inhibitory control in children and adults [103-105]. Partial sleep deprivation of one to two nights impaired the performance at behavioral tasks and Go/No-Go task, measuring inhibitory control in adults [103,104]. Similarly, moderate sleep deprivation of one week negatively impacted the inhibitory control tasks in school-aged children when compared with those having non-deprived sleep [105]. Moreover, inhibitory control abilities improve by increasing sleep duration in children [96].

Cognitive flexibility is also positively linked with sleep duration in adolescents. An addition of five minutes in sleep duration for two weeks demonstrated a positive impact on the Divided Attention task in chronically sleep deprived adolescents [106]. Single night sleep limitation (5 h) in children aged 10-14 years lead to declined cognitive flexibility and verbal creativity [107], but response inhibition and sustained attention remained unimpaired in children aged 8-15 years [108].

Poor sleep has been linked to an increased risk of obesity among children and adults [109-112]. There is also some evidence that short sleep length is associated with unhealthy diet and eating patterns that favor energy dense foods, such as fast food and candy, in children and adolescents [113,114]. A recent study found that shorter sleep duration $(<8 \mathrm{~h})$ in adolescents is related to an increased consumption of fats and a decreased intake of carbohydrates that may predispose them to an increased risk of obesity [115]. Overall, most of the observational and experimental studies have found cross-sectional associations between short sleep duration $(<8 \mathrm{~h}$ per night) and increased body mass index or obesity, impaired glucose metabolism, and dysregulation of appetite, but the longitudinal evidence to establish the causal relationship is still limited [116]. 


\subsection{Nutrition and the Brain}

Nutrition plays crucial role throughout life in the development and protection of the brain and cognition [117]. Diet quality is important from childhood to adolescence for various brain functions such as neurogeneration, axonal and dendritic growth, synaptic formation, and the myelination of axons [36]. Inadequate and low intake of energy, protein, fatty acids, and micronutrients disrupt these neurodevelopmental processes [36]. Here, we elaborate on the association of nutrients, food, and dietary patterns with cognition and academic achievement in children and adolescents.

\subsubsection{Nutrients, Cognition, and Academic Achievement}

The evidence from previous studies suggest that a higher or adequate intake of some nutrients, such as polyunsaturated fatty acids (PUFAs), and a lower intake of saturated fatty acids are related to better cognitive functions and academic achievement in children [118-120].

A higher dietary intake of PUFAs has been related to better short-term memory in children [120-122]. The results of one study suggested that replacing carbohydrates or saturated fat with PUFAs was associated with better short term memory [122]. Few studies have investigated the associations of the plasma biomarkers of PUFA status with cognition in children and these studies have provided inconsistent results [122,123]. Montgomery et al. [123] found no association between the proportion of docosahexaenoic acid (DHA) in blood and working memory, but observed a direct relationship between the proportion of combined DHA and eicosapentaenoic acid (EPA) in blood and working memory in children. Boucher et al. [122] found no associations between the proportions of DHA, EPA, or other n-3 fatty acids in blood phospholipids and working memory in children. One study found that higher plasma proportions of EPA and DHA and EPA to the Arachidonic acid ratio were associated with better reasoning skills in overweight and obese children, but not in normal weight children [124]. Furthermore, one study found that increased whole-blood DHA and EPA concentrations after a three month school meal intervention were related to greater improvements in reading performance in 9 to 11-year old children [125]. However, the results of the Special Turku Coronary Risk Factor Intervention Project (STRIP) Study suggested that a limiting dietary fat intake, while increasing the proportion of PUFA and monounsaturated fatty acids, had no effect on language skills in young children [126].

Studies have suggested that a higher intake of n-3 PUFA supplements, especially DHA, may improve cognitive functions during the perinatal period and infancy, but not in childhood or adulthood [118,122,127,128]. Recently, Johnson et al. [129], however, found that the increased intake of omega 3 and 6 fatty acids (DHA, EPA, and gamma-linolenic acid) for three months had a positive effect on prerequisites of reading and that the effects were particularly strong among those with a poorer attention.

Zhang et al. [120] found an inverse association of dietary cholesterol intake with working memory among 6-16-year-old children and adolescents. Baym et al. [119] observed inverse associations of the consumption of saturated and trans-fats with working memory in school-aged children aged 7-9.

The chronically increased consumption of fructose may have deleterious effects on the brain [130]. Fructose ingestion has been observed to decrease blood flow to the hippocampus in mice [131]. Increased blood flow and blood volume in the hippocampus has been linked to increased neurogenesis in the dentate gyrus [132]. Furthermore, high fructose intake has been found to exacerbate the negative effects of DHA deficient diets on synaptic plasticity in a rodent model [133]. A diet that is high in saturated fat and fructose has been found to decrease insulin signaling in the hippocampus and decrease hippocampal weight, impair the dendritic tree, decrease synaptophysin content, and increase tau phosphorylation [134]. A regular consumption of sucrose sweetened beverages may also increase amyloid- $\beta$ levels and accumulation in the brain [135].

A higher intake of total fiber and insoluble fiber has been linked to better cognitive control in children [128]. Furthermore, breakfast with a lower glycemic load acutely improved working memory in 5-11-year-old children [136]. 
A protein and energy rich formula during infancy had a positive association with caudate nucleus volume and verbal IQ at the age of 10, than those who were fed with the standard formula among pre-term children [137].

In addition to macronutrients, micronutrients are also important for brain development. Inadequate intake of micronutrients such as iron, iodine, zinc, and vitamins B, D, and E, have been found to impair neuronal proliferation, axonal and dendritic growth, synaptic formation, pruning, and function, and axonal myelination $[36,138,139]$. A systemic review of randomized controlled trials among children aged 4-18 demonstrated an improvement in fluid intelligence after micronutrient supplementation, especially among those having iron or iodine-deficiency at baseline, but the results among healthy subjects without nutritional deficiencies remain inconsistent [140].

\subsubsection{Foods, Cognition, and Academic Achievement}

Food is the combination of various nutrients, therefore, undernourishment and low availability of nutritionally adequate and safe foods has been observed to decrease cognitive functions in children [141,142]. Higher consumption fish has been linked to better cognition and academic achievement in children and adolescents [143-145]. In a Norwegian study, a higher consumption of fruit, especially berries, was related to better academic achievement in female and male adolescents, while a higher consumption of vegetables was only related to better academic performance in adolescent girls aged 15-17 years [146]. Some other studies have also reported a direct relationship between vegetable consumption and academic performance [144,147]. Furthermore, low consumption of fruit, berries, vegetables, and high-fiber grain products and high consumption of red meat have been associated with poorer cognition in children aged 6-8 years [148].

Finally, the results of some studies suggest that a higher consumption of soft drinks and sweet beverages is related to poorer academic achievement [144].

\subsubsection{Dietary Patterns, Diet Quality Indices, Cognition, and Academic Achievement}

Dietary patterns and diet quality indices have been suggested to better reflect a real-life diet because nutrients do not naturally exist in isolation. Food is the combination of various nutrients that act synergistically and are interrelated $[29,149]$. There are various dietary scores and indices used to assess the dietary patterns and diet quality, for example, Mediterranean dietary score, Baltic Sea Diet Score (BSDS), Dietary Approaches to Stop Hypertension (DASH) score, Finnish Children Healthy Eating Index (FCHEI), and the Healthy Eating Index.

While evidence on the associations of dietary patterns with academic achievement is limited, some studies suggest a direct relationship of adherence to the Mediterranean style diet assessed by the KIDMED index $[150,151]$ and the Healthy Eating Index [147] with academic achievement in children and adolescents. The Healthy Eating Index 2005 has been linked to better cognitive control in 7-9-year-old children [128]. A higher BSDS reflecting a better adherence to healthy diet in the Nordic countries and the better adherence to the DASH diet have been linked to better cognition in children and particularly in boys aged 6-8 [143].

Recently, a healthier diet assessed by the BSDS and the FCHEI in Grade 1 was related to better reading skills in Grades 1-3 in Finnish children [148]. However, a Mediterranean Diet Score reflecting Mediterranean style diet was not associated with academic performance [148].

A three month randomized controlled school lunch trial showed that healthy Nordic diet improved reading skills, but impaired attention in children aged 10 years [152]. However, in contrast to some previous studies, the effects of the intervention were stronger in boys, in those from families with more educated parents, and in those with normal/good baseline reading skills [153].

A dietary pattern high in fruits, vegetables, and home-prepared foods at the age of 6 and 12 months has been associated with better cognitive function at the age of four [154]. Fruits, especially berries, vegetables, green tea, red wine, and chocolate are rich in flavonoids. A higher intake of flavonoids has been associated with better cognition [32]. Flavonoids are polyphenols and have been suggested 
to protect neurons against neurotoxin-induced injuries, decrease neuroinflammation, and increase neuroprotective signaling [32,138].

Dietary patterns, including a high consumption of sausage, fast food, snacks, and sugar sweetened beverages at the age of three years, has been related to poorer academic achievement at the age of 10 years among children [155]. Western dietary patterns that are high in take-away foods, red and processed meat, soft drinks, and fried and refined food has been linked to poorer cognition at the age of 17 [156].

\section{Discussion}

The current review provides an elaborated overview of existing literature on the associations of health behaviors, including diet quality and dietary intakes, physical activity, sedentary activities, and sleep with brain structure and function, cognition, and academic achievement in children and adolescents under 18 years of age, with a special reference to diet quality. However, this review is not systematic and all the relevant studies were not described. Therefore, this review should not be treated as the exhausting evidence synthesis. Instead, we aimed to provide generalized view of available literature on the topic. Furthermore, we did not review the associations of other health behaviors, such as smoking or alcohol or substance abuse, with brain structure and function, cognition, and academic achievement. Therefore, we cannot exclude the possibility that they effect on the results of reviewed studies.

\subsection{Health Behaviors and Cogntion}

Despite the increased interest, the evidence on the associations of nutritional factors, physical activity, sedentary activities, and sleep with brain structure and function, cognition, and academic achievement in children and adolescents is still mainly based on cross-sectional studies with mixed results.

Some cross-sectional studies have found direct associations of physical activity with cognitive functions, including learning and academic outcomes, and neuroelectric processing in children [157,158]. Other studies have found no relationship or they have found inverse associations between physical activity, physical fitness, and cognitive functions in children and adolescents $[47,48,159]$. A few interventional studies with varying study protocols have provided some evidence that increasing after-school or classroom physical activity may improve cognitive functions, neural processing, and academic achievement in children $[33,54,63,158,160]$. However, some studies also suggest that increasing the time allocated to physical activity has no effect on cognition or academic achievement $[41,52,57]$. Higher physical fitness has been linked to better cognition and academic achievement in children [33]. Prospective investigations on the associations between physical fitness, cognition, and academic achievement are few, but the evidence from these studies indicate that children and adolescents who maintain high levels of physical fitness have better cognitive and academic performance than those who have consistently low levels of physical fitness [33,161-163]. These studies have shown that changes in physical fitness during follow-up have only weak associations with the changes in cognitive functions or academic achievement [161-163]. Furthermore, most studies have investigated the associations of cardiorespiratory fitness with cognition and academic achievement [33], although the results of some studies indicate that motor skill training and motor skills have a stronger relationship to cognition and academic achievement than cardiorespiratory fitness in children $[65,67]$.

Sedentary behaviors, such as reading and drawing, may be associated with improved cognitive functions and academic performance in children [74]. In contrast, sedentary behaviors with high levels of screen time have been associated with poorer cognitive functions and academic achievement in children and adolescents [70-72]. The inverse associations of screen time with cognition and academic performance may also be partly due to the unhealthy snacking on energy dense food and a lower consumption of fruit and vegetables while watching television [75]. 
The sleep duration and quality have directly linked with all three subcomponents of executive function, i.e., working memory, inhibitory control, and cognitive flexibility. Children's age has been found to be a substantial moderator of the association of sleep duration and quality with children's school performance; younger children showed a stronger relationship than older children [94]. It is also believed that sleep restriction impairs the complex cognitive functions more than the general cognitive abilities such as language and knowledge in children $[95,96]$. Poor sleep and short sleep length is associated with unhealthy diets and eating patterns favoring energy dense foods, such as fast food and candy, in children and adolescents [113,114]. Overall, most of the observational and experimental studies have found cross-sectional associations between short sleep duration $(<8 \mathrm{~h}$ per night) and increased body mass index or obesity, impaired glucose metabolism, and dysregulation of appetite, but the longitudinal evidence to establish the causal relationship is still limited [117].

\subsection{Nutrition and Diet Quality.}

Diet may have direct and indirect effects on the brain (Figure 1). However, the direct and indirect effects of diet on the brain are often overlapping and synergistic $[29,83]$. Undernourishment and the low availability of nutritionally adequate and safe foods have been observed to decrease cognitive functions in children [141,142].

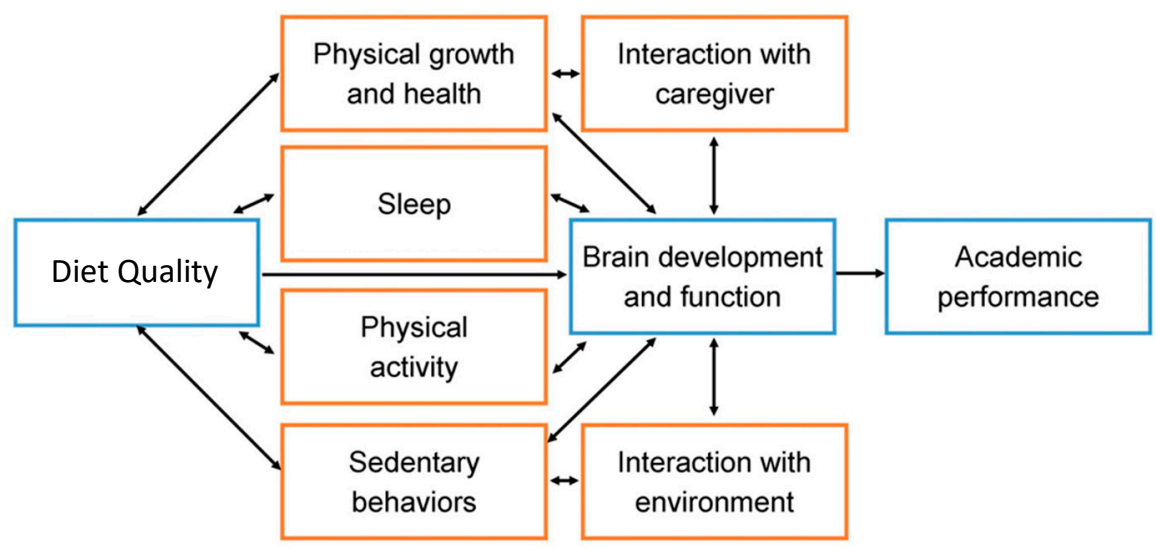

Figure 1. Hypothetical and simplified model on the direct and indirect effects of nutritional status and diet on brain development and academic performance in children (adapted from Reference [36]).

The evidence suggests that the low intake of PUFAs, especially DHA and EPA during early years, may attenuate brain and cognitive development. A low consumption of fish, fruit and berries, and vegetables, and a high consumption of fast foods, have been linked to poorer cognitive functions and academic achievement in children and adolescents. The results of some studies also suggest that dietary patterns high in vegetables and fruits are directly and dietary patterns high in fast food, sausages, and soft-drinks are inversely associated with cognition. Furthermore, diet quality indices such as different Mediterranean diet scores, the DASH diet score, the Healthy Eating Index, and the Baltic Sea Diet Score have been directly related to cognition and academic achievement. There are also some but still very limited evidence on the associations of high intake of saturated fat and low intake of fiber and low consumption of high-fiber grain products and high consumption of red meat with cognition in children and adolescents. There are promising results that increasing DHA and EPA intake and improving a quality of school lunches may improve cognition and academic performance, but the evidence is limited. These are summarized in Table 1. 
Table 1. Associations of dietary factors with cognition and academic performance.

\begin{tabular}{|c|c|}
\hline Dietary Factors & Evidence in Relation Cognitive Functions \\
\hline \multicolumn{2}{|c|}{ Nutrients, cognition and academic achievement } \\
\hline Iron & $\begin{array}{l}\text { Iron deficiency leading to anemia may negatively } \\
\text { impact on brain and cognitive development }\end{array}$ \\
\hline Docosahexaenoic acid and eicosapentaenoic acid & $\begin{array}{l}\text { Low intake during early years may attenuate brain } \\
\text { and cognitive development }\end{array}$ \\
\hline \multicolumn{2}{|c|}{ Foods, cognition and academic achievement } \\
\hline Fish & $\begin{array}{l}\text { A higher consumption of fish has been associated } \\
\text { with better cognitive functions }\end{array}$ \\
\hline Fruit, berries, and vegetables & $\begin{array}{l}\text { A higher consumption of fruit, berries, and vegetables } \\
\text { have been associated with better cognitive functions }\end{array}$ \\
\hline Fast foods & $\begin{array}{l}\text { A higher consumption of fast foods has been } \\
\text { associated with poorer cognitive functions }\end{array}$ \\
\hline \multicolumn{2}{|c|}{ Dietary patterns, diet quality indices, cognition and academic achievement } \\
\hline Dietary patterns & $\begin{array}{l}\text { Dietary patterns high in vegetables, fruits, and } \\
\text { home-prepared foods have been associated with } \\
\text { better cognitive functions. } \\
\text { Dietary patterns high in fast foods, red meat, } \\
\text { soft-drinks, and fried and refined foods have been } \\
\text { linked to poorer cognitive functions }\end{array}$ \\
\hline $\begin{array}{l}\text { Diet quality indices (DASH, BSDS, FCHEI, } \\
\text { KIDMEX, HEI-2005) }\end{array}$ & $\begin{array}{l}\text { A better adherence to pre-specified diets (i.e., higher } \\
\text { scores) has been associated with better cognitive } \\
\text { functions and academic performance }\end{array}$ \\
\hline
\end{tabular}

Abbreviations: DASH, Dietary Approaches to Stop Hypertension; BSDS, Baltic Sea Diet Score; FCHEI, Finnish Children Healthy Eating Index; HEI-2005, Healthy Eating Index 2005.

While the evidence on the associations of PUFA with cognition and academic achievement in children and adolescents is still limited, the positive association between PUFA and brain health is physiologically plausible. PUFAs are essential for normal brain development [164] as they regulate cell membrane dynamics and modulate the endocannabinoid system that, in turn, regulates neurotransmission and participates in synaptic plasticity [164]. n-3 PUFA DHA has been linked to neurogenesis and neural survival [164]. A higher intake of DHA may also reduce apoptotic signaling in the brain and increase brain derived neurotrophic factor (BDNF) concentration [164]. BDNF has been found to improve neural survival, neural maintenance, neurogenesis, synaptic plasticity, long-term potentiation, and neurotransmitter release $[68,132,138]$. Furthermore, the results of some studies suggest an inverse association between the dietary intake of saturated fat and BDNF [165]. Similarly, a diet high in saturated fat may have adverse effects on synapsin I, growth associated protein 43 (GAP-43), and cyclic AMP response element-binding protein (CREB), which have been linked to synaptic plasticity, neurotransmitter release, and axonal growth [165].

A Western diet usually denotes a diet high in saturated fat and refined carbohydrates $[83,165]$. Most studies on the effects that Western diets have manipulated the consumption of saturated fat and refined carbohydrates [83]. A diet high in saturated fatty acids and refined carbohydrates has been linked to increased oxidative stress and a subsequent decrease in hippocampal BDNF, and impaired BDNF-related synaptic plasticity $[68,165]$. A Western diet may impair brain health and cognition directly or indirectly. A diet high in saturated fat and refined carbohydrates may cause insulin resistance, reduce BDNF and other neurotrophin concentrations, and thereby impair synaptic plasticity and neurogenesis in the hippocampus, increase neuroinflammation, and alter the blood-brain barrier $[83,165]$. Alterations in the blood-brain barrier permeability may increase the permeability of toxins and $\beta$-amyloid peptides and thereby impair brain health and cognitive functions [86]. 
Dietary patterns and diet quality indices have been suggested to better reflect a real life diet and the improvements in dietary patterns may be more easily translated to real life conditions than those in single nutrients, because single nutrients do not normally exist in isolation and are interrelated and synergistic $[29,149]$. There are also differences in food cultures and food choices between geographical regions and populations. While the Mediterranean style diet has frequently been used to describe healthy diets [29], it may not be easily translated to other countries, such as the Nordic countries. However, there seems to be some specific nutrients that have a pronounce effect on the brain and cognition. For example, PUFAs has been found to be essential for normal brain development [164] and a recent study suggested that increased DHA and EPA levels explained approximately $20 \%$ of the effects of school-lunch intervention on academic performance in children [152]. However, the results of some cross-sectional studies are not as straightforward. Khan et al. [128] found a positive association between intake of dietary fiber and response accuracy in the Flanker task, but no association of intake of dietary fiber and the ability to sustain response accuracy between two task requiring different amounts of cognitive control. However, they found that the Healthy Eating Index 2015 was inversely associated with the interference score, suggesting that children with a healthier diet were better able to sustain the response accuracy with increasing cognitive demands. Another study found that low consumption of fruit, berries, vegetables, and high-fiber grain products and high consumption of red meat have been associated with poorer cognition in children aged 6-8-years [143]. Nevertheless, Baltic Sea Diet Score and the DASH score had stronger associations with cognition than any single food item [143].

Better adherence to different diet quality indices and healthier dietary patters have been associated with better cognitive functions and academic achievement $[128,143,147,148,151]$. These diet quality indices mostly describe a diet high in vegetables, fruit and berries, high fiber grain products, and fish and low in fast foods, saturated fat, and refined carbohydrates. However, some studies have observed that that the magnitude of the associations of different diet quality indices with cognition and academic performance are not equal. One study found that while the Baltic Sea Diet Score and Finnish Children Healthy Eating Index were directly related to academic performance in Finnish children aged 6-8 years, Mediterranean Diet Score was not related to academic performance [148]. The authors speculated that these differences in the strength of the associations might be explained by the low variance in the Mediterranean diet score or differences in the components emphasized. For example, while the Baltic Sea Diet Score and Finnish Children Healthy Eating Index emphasize the intake of polyunsaturated fatty acids and the consumption low-fat milk, whereas the Mediterranean diet score gives emphasis to the ratio of monounsaturated to saturated fatty acids and low consumption of milk. Milk is commonly fortified with vitamin D in Finland, and it is the major dietary source of vitamin D among Finnish children. Furthermore, another study found a stronger association of Baltic Sea Diet Score than the DASH score with cognition [143]. These results may also indicate that diet quality indices developed for specific geographical locations and by using some specific components may better reflect a healthy diet than diet quality indices developed for other cultures. Nevertheless, the evidence from these studies suggest that a diet high in vegetables, fruit and berries, and fish are linked to better cognition and academic performance in children and adolescents.

\section{Conclusions}

The aim of this review was to provide an overview on the associations of health behaviors with brain structure and function, cognition, and academic achievement in children and adolescents with a special reference to diet quality. Overall, there is some evidence that in addition to poor diet quality, excess adiposity, increased cardiometabolic risk, physical inactivity, high levels of screen-time, poor physical fitness, and low levels of sleep may impair cognitive functions and academic performance in children and adolescents. While the available evidence and physiological mechanisms suggest that diet may have direct, indirect, and synergistic effects on the brain and cognition with physical activity, sedentary behaviors, cardiometabolic health, and sleep, the associations are modest. The evidence also suggests that diet and physical activity have at least partly different pathways [68]. Accordingly, 
some studies have found that a healthier diet is related to better cognition and academic performance, independent of physical activity, sedentary behaviors, or physical fitness $[143,148]$. While they seem to be related to cognition, independent of each other, the magnitude of the effects has been modest. Therefore, it is possible that integrating healthy diet, physically active lifestyle, and adequate levels of sleep would provide optimal circumstances for brain development and learning during childhood and adolescence. However, the evidence is mostly based on cross-sectional data, and there is need for longitudinal and intervention studies on the effects of diet, physical activity, sedentary behavior, and sleep on cognition and academic performance in children and adolescents and to expose the complex interactions among these health related behaviors.

Author Contributions: Conceptualization, S.N., T.L. and E.A.H.; methodology, S.N. and E.A.H.; writing-original draft preparation, S.N.; writing-review and editing, T.L. and E.A.H.; supervision, T.L. and E.A.H.; funding acquisition, E.A.H. All authors have read and agreed to the published version of the manuscript.

Funding: A part of this work was financially supported by the Fazer Group.

Conflicts of Interest: The authors declare no conflict of interest. The funders had no role in the design of the study; in the collection, analyses, or interpretation of data; in the writing of the manuscript, or in the decision to publish the results.

\section{References}

1. Nyaradi, A.; Li, J.; Hickling, S.; Foster, J.; Oddy, W.H. The role of nutrition in children's neurocognitive development, from pregnancy through childhood. Front. Hum. Neurosci. 2013, 7, 97. [CrossRef]

2. Alatupa, S.; Pulkki-Råback, L.; Hintsanen, M.; Ravaja, N.; Raitakari, O.T.; Telama, R.; Viikari, J.S.A.; Keltikangas-Järvinen, L. School performance as a predictor of adulthood obesity: A 21-year follow-up study. Eur. J. Epidemiol. 2010, 25, 267-274. [CrossRef] [PubMed]

3. Kokko, K.; Pulkkinen, L. Aggression in childhood and long-term unemployment in adulthood: A cycle of maladaptation and some protective factors. Dev. Psychol. 2000, 36, 463-472. [CrossRef] [PubMed]

4. Alatupa, S.; Pulkki-Råback, L.; Hintsanen, M.; Elovainio, M.; Mullola, S.; Keltikangas-Järvinen, L. Disruptive behavior in childhood and socioeconomic position in adulthood: A prospective study over 27 years. Int. J. Public Health 2013, 58, 247-256. [CrossRef] [PubMed]

5. Sijtsma, F.; Meyer, K.; Steffen, L.; Shikany, J.; van Horn, L.; Harnack, L.; Kromhout, D.; Jacobs, D., Jr. Longitudinal trends in diet and effects of sex, race, and education on dietary quality score change: The Coronary Artery Risk Development in Young Adults study. Am. J. Clin. Nutr. 2012, 95, 580-586. [CrossRef] [PubMed]

6. Cheng, G.; Libuda, L.; Karaolis-Danckert, N.; Alexy, U.; Bolzenius, K.; Remer, T.; Buyken, A.E. Trends in dietary carbohydrate quality during puberty from 1988 to 2007: A cause for concern? Br. J. Nutr. 2010, 104, 1375-1383. [CrossRef]

7. Bauer, K.W.; Larson, N.I.; Nelson, M.C.; Story, M.; Neumark-Sztainer, D. Fast food intake among adolescents: Secular and longitudinal trends from 1999 to 2004. Prev. Med. 2009, 48, 284-287. [CrossRef]

8. Eloranta, A.M.; Lindi, V.; Schwab, U.; Kiiskinen, S.; Kalinkin, M.; Lakka, H.M.; Lakka, T.A. Dietary factors and their associations with socioeconomic background in Finnish girls and boys 6-8 years of age: The PANIC Study. Eur. J. Clin. Nutr. 2011, 65, 1211-1218. [CrossRef]

9. Larson, N.I.; Neumark-Sztainer, D.; Hannan, P.J.; Story, M. Trends in adolescent fruit and vegetable consumption, 1999-2004: Project EAT. Am. J. Prev. Med. 2007, 32, 147-150. [CrossRef]

10. Arundell, L.; Fletcher, E.; Salmon, J.; Veitch, J.; Hinkley, T. A systematic review of the prevalence of sedentary behavior during the after-school period among children aged 5-18 years. Int. J. Behav. Nutr. Phys. Act. 2016, 13, 93. [CrossRef]

11. Colley, R.; Garriguet, D.; Janssen, I.; Craig, C.; Clarce, J.; Tremblay, M. Physical activity of Canadian children and youth: Accelometer results from the 2007-2009 Health Measures Survey. Health Rep. 2011, 22, 15-22. [PubMed]

12. Carson, V.J.I.; Tremblay, C.J.-P. Health associations with meeting new 24-h movement guidelines for Canadian children and youth. Int. J. Behav. Nutr. Phys. Act. 2016, 25, 123. [CrossRef] [PubMed] 
13. Chaput, J.; Gray, C.E.; Poitras, V.J.; Carson, V.; Gruber, R.; Olds, T.; Weiss, S.K.; Gorber, S.C.; Kho, M.E.; Sampson, M.; et al. Systematic review of the relationships between sleep duration and health indicators in school-aged children and youth. Appl. Physiol. Nutr. Metab. 2016, 282, 266-282. [CrossRef] [PubMed]

14. Matricciani, L.; Olds, T.; Petkov, J. In search of lost sleep: Secular trends in the sleep time of school-aged children and adolescents. Sleep Med. Rev. 2012, 16, 203-211. [CrossRef]

15. Cain, N.; Gradisar, M. Electronic media use and sleep in school-aged children and adolescents: A review. Sleep Med. 2010, 11, 735-742. [CrossRef]

16. Hales, C.M.; Carroll, M.D.; Fryar, C.D.; Ogden, C.L. Prevalence of Obesity among Adults and Youth: United States, 2015-2016 Key findings Data from the National Health and Nutrition Examination Survey; CDC: Hyattsville, MD, USA, 2015.

17. Garrido-Miguel, M.; Oliveira, A.; Cavero-Redondo, I.; Álvarez-Bueno, C.; Pozuelo-Carrascosa, D.P.; Soriano-Cano, A.; Martínez-Vizcaíno, V. Prevalence of Overweight and Obesity among European Preschool Children: A Systematic Review and Meta-Regression by Food Group Consumption. Nutrients 2019, 11, 1698. [CrossRef]

18. Ahrens, W.; Breda, J.; Buoncristiano, M.; Rito, A.; Spinelli, A.; Whiting, S.; Wirsik, M. WHO European Childhood Obesity Surveillance Initiative: Overweight and obesity among 6-9-year-old children; WHO regional office Europe: Copenhagen, Denmark, 2018.

19. Kaikkonen, R.; Hakulinen-viitanen, T.; Markkula, J.; Ovaskainen, M.; Virtanen, S.; Laatikainen, T. Lasten ja lapsi- perheiden terveys- ja hyvinvointierot; National Institute for Health and Welfare (THL): Helsinki, Finland, 2012.

20. Vuorela, N.; Saha, M.-T.; Salo, M. Prevalence of overweight and obesity in 5- and 12-year-old Finnish children in 1986 and 2006. Acta Paediatr. 2009, 98, 507-512. [CrossRef]

21. Mäki, P.; Lehtinen-Jacks, S.; Vuorela, N.; Levälahti, E.; Koskela, T.; Saari, A.; Mölläri, K.; Mahkonen, R.; Salo, J.; Laatikainen, T. Tilastotietoa lasten ylipainoisuuden yleisyydestä saatavilla yhä useammasta kunnasta; National Institute for Health and Welfare (THL): Helsinki, Finland, 2018.

22. Solfrizzi, V.; Panza, F.; Frisardi, V.; Seripa, D.; Logroscino, G.; BP, I.; Pilotto, A. Diet and Alzheimer's disease risk factors or prevention: The current evidence. Expert. Rev. Neurother. 2011, 11, 677-708. [CrossRef]

23. Kalmijn, S.; van Boxtel, M.P.J.; Ocke, M.; Verschuren, W.M.M.; Kromhout, D.; Launer, L.J. Dietary intake of fatty acids and fish in relation to cognitive performance at middle age. Neurology 2004, 62, 275-280. [CrossRef]

24. Eskelinen, M.; Ngandu, T.; Helkala, E.-L.; Tuomilehto, J.; Nissinen, A.; Soininen, H.; Kivipelto, M. Fat intake at midlife and cognitive impairment later in life: A population-based CAIDE study. Int. J. Geriatr. Psychiatry 2008, 23, 741-747. [CrossRef]

25. Laitinen, M.H.; Ngandu, T.; Rovio, S.; Helkala, E.L.; Uusitalo, U.; Viitanen, M.; Nissinen, A.; Tuomilehto, J.; Soininen, H.; Kivipelto, M. Fat intake at midlife and risk of dementia and Alzheimer's disease: A population-based study. Dement. Geriatr. Cogn. Disord. 2006, 22, 99-107. [CrossRef] [PubMed]

26. Féart, C.; Samieri, C.; Allès, B.; Barberger-Gateau, P. Potential benefits of adherence to the Mediterranean diet on cognitive health. Proc. Nutr. Soc. 2013, 72, 140-152. [CrossRef] [PubMed]

27. Männikkö, R.; Komulainen, P.; Schwab, U.; Heikkilä, H.M.; Savonen, K.; Hassinen, M.; Hänninen, T.; Kivipelto, M.; Rauramaa, R. The Nordic diet and cognition-The DR's EXTRA Study. Br. J. Nutr. 2015, 1-9. [CrossRef] [PubMed]

28. Wengreen, H.; Munger, R.; Cutler, A.; Quach, A.; Bowles, A.; Corcoran, C.; Tschanz, J.; Norton, M.; Wehls-Bohmer, K. Prospective study of Dietary Approaches to Stop Hypertension-and Mediterranean-style dietary patterns and age-related cognitive change: The Cache County Study in Memory, Health and Aging. Am. J. Clin. Nutr. 2013, 98, 1263-1271. [CrossRef]

29. Allès, B.; Samieri, C.; Féart, C.; Jutand, M.-A.; Laurin, D.; Barberger-Gateau, P. Dietary patterns: A novel approach to examine the link between nutrition and cognitive function in older individuals. Nutr. Res. Rev. 2012, 25, 207-222. [CrossRef]

30. Kivipelto, M.; Ngandu, T.; Fratiglioni, L.; Viitanen, M.; Kåreholt, I.; Winblad, B.; Helkala, E.-L.; Tuomilehto, J.; Soininen, H.; Nissinen, A. Obesity and vascular risk factors at midlife and the risk of dementia and Alzheimer disease. Arch. Neurol. 2005, 62, 1556-1560. [CrossRef] 
31. Ngandu, T.; Lehtisalo, J.; Solomon, A.; Levälahti, E.; Ahtiluoto, S.; Antikainen, R.; Bäckman, L.; Hänninen, T.; Jula, A.; Laatikainen, T.; et al. A 2 year multidomain intervention of diet, exercise, cognitive training, and vascular risk monitoring versus control to prevent cognitive decline in at-risk elderly people (FINGER): A randomised controlled trial. Lancet 2015, 6736, 1-9. [CrossRef]

32. Meeusen, R. Exercise, nutrition and the brain. Sports Med. 2014, 44 (Suppl. 1), S47-S56. [CrossRef]

33. Donnelly, J.E.; Hillman, C.H.; Castelli, D.; Etnier, J.L.; Lee, S.; Tomporowski, P.; Lambourne, K.; Szabo-Reed, A.N. Physical Activity, Fitness, Cognitive Function, and Academic Achievement in Children: A Systematic Review. Med. Sci. Sports Exerc. 2016, 48, 1197-1222. [CrossRef]

34. Stringhini, S.; Dugravot, A.; Shipley, M.; Goldberg, M.; Zins, M.; Kivimäki, M.; Marmot, M.; Sabia, S.; Singh-Manoux, A. Health Behaviours, Socioeconomic Status, and Mortality: Further Analyses of the British Whitehall II and the French GAZEL Prospective Cohorts. PLoS Med. 2011, 8, e1000419. [CrossRef]

35. Vaynman, S.; Gomez-pinilla, F. Review Revenge of the "Sit": How Lifestyle Impacts Neuronal and Cognitive Health through Molecular Systems That Interface Energy Metabolism with Neuronal Plasticity. J. Neurosci. Res. 2006, 715, 699-715. [CrossRef] [PubMed]

36. Prado, E.L.; Dewey, K.G. Nutrition and brain development in early life. Nutr. Rev. 2014, 72, $267-284$. [CrossRef] [PubMed]

37. Tandon, P.S.; Tovar, A.; Jayasuriya, A.T.; Welker, E.; Schober, D.J.; Copeland, K.; Dev, D.A.; Murriel, A.L.; Amso, D.; Ward, D.S. The relationship between physical activity and diet and young children's cognitive development: A systematic review. Prev. Med. Rep. 2016, 3, 379-390. [CrossRef]

38. Mandolesi, L.; Polverino, A.; Montuori, S.; Foti, F.; Ferraioli, G.; Sorrentino, P.; Sorrentino, G. Effects of physical exercise on cognitive functioning and wellbeing: Biological and psychological benefits. Front. Psychol. 2018, 9, 509. [CrossRef]

39. Coelho, F.G. de M.; Gobbi, S.; Andreatto, C.A.A.; Corazza, D.I.; Pedroso, R.V.; Santos-Galduróz, R.F. Physical exercise modulates peripheral levels of brain-derived neurotrophic factor (BDNF): A systematic review of experimental studies in the elderly. Arch. Gerontol. Geriatr. 2013, 56, 10-15. [CrossRef]

40. Erickson, K.I.; Voss, M.W.; Prakash, R.S.; Basak, C.; Szabo, A.; Chaddock, L.; Kim, J.S.; Heo, S.; Alves, H.; White, S.M.; et al. Exercise training increases size of hippocampus and improves memory. Proc. Natl. Acad. Sci. USA 2011, 108, 3017-3022. [CrossRef] [PubMed]

41. Chaddock-Heyman, L.; Erickson, K.I.; Voss, M.W.; Knecht, A.M.; Pontifex, M.B.; Castelli, D.M.; Hillman, C.H.; Kramer, A.F. The effects of physical activity on functional MRI activation associated with cognitive control in children: A randomized controlled intervention. Front. Hum. Neurosci. 2013, 7, 72. [CrossRef]

42. Hötting, K.; Röder, B. Beneficial effects of physical exercise on neuroplasticity and cognition. Neurosci. Biobehav. Rev. 2013, 37, 2243-2257. [CrossRef]

43. Haapala, E.A.; Väistö, J.; Lintu, N.; Tompuri, T.; Brage, S.; Westgate, K.; Ekelund, U.; Lampinen, E.-K.; Sääkslahti, A.; Lindi, V.; et al. Adiposity, physical activity and neuromuscular performance in children. J. Sports Sci. 2016, 34, 1699-1706. [CrossRef]

44. Syväoja, H.J.; Tammelin, T.H.; Ahonen, T.; Kankaanpää, A.; Kantomaa, M.T. The Associations of Objectively Measured Physical Activity and Sedentary Time with Cognitive Functions in School-Aged Children. PLoS ONE 2014, 9, e103559. [CrossRef]

45. Booth, J.N.; Leary, S.D.; Joinson, C.; Ness, A.R.; Tomporowski, P.D.; Boyle, J.M.; Reilly, J.J. Associations between objectively measured physical activity and academic attainment in adolescents from a UK cohort. Br. J. Sports Med. 2014, 48, 265-270. [CrossRef] [PubMed]

46. Maher, C.; Lewis, L.; Katzmarzyk, P.T.; Dumuid, D.; Cassidy, L.; Olds, T. The associations between physical activity, sedentary behaviour and academic performance. J. Sci. Med. Sport 2016, 19, 1004-1009. [CrossRef] [PubMed]

47. Syväoja, H.J.; Kantomaa, M.T.; Ahonen, T.; Hakonen, H.; Kankaanpää, A.; Tammelin, T.H. Physical Activity, Sedentary Behavior, and Academic Performance in Finnish Children. Med. Sci. Sports Exerc. 2013, 45, 2098-2104. [CrossRef] [PubMed]

48. Esteban-Cornejo, I.; Tejero-González, C.M.; Martinez-Gomez, D.; Cabanas-Sánchez, V.; Fernández-Santos, J.R.; Conde-Caveda, J.; Sallis, J.F.; Veiga, O.L. Objectively measured physical activity has a negative but weak association with academic performance in children and adolescents. Acta Paediatr. 2014, 103, e501-e506. [CrossRef] [PubMed] 
49. LeBlanc, M.M.; Martin, C.K.; Han, H.; Newton, R.; Sothern, M.; Webber, L.S.; Davis, A.B.; Williamson, D.A.; Williamson, D.A. Adiposity and physical activity are not related to academic achievement in school-aged children. J. Dev. Behav. Pediatr. 2012, 33, 486-494. [CrossRef] [PubMed]

50. Kamijo, K.; Pontifex, M.B.; O’Leary, K.C.; Scudder, M.R.; Wu, C.-T.; Castelli, D.M.; Hillman, C.H. The effects of an afterschool physical activity program on working memory in preadolescent children. Dev. Sci. 2011, 14, 1046-1058. [CrossRef]

51. Hillman, C.H.; Pontifex, M.B.; Castelli, D.M.; Khan, N.A.; Raine, L.B.; Scudder, M.R.; Drollette, E.S.; Moore, R.D.; Wu, C.-T.; Kamijo, K. Effects of the FITKids Randomized Controlled Trial on Executive Control and Brain Function. Pediatrics 2014, 134, e1063-e1071. [CrossRef]

52. De Greeff, J.W.; Hartman, E.; Mullender-Wijnsma, M.J.; Bosker, R.J.; Doolaard, S.; Visscher, C. Long-term effects of physically active academic lessons on physical fitness and executive functions in primary school children. Health Educ. Res. 2016, 31, 185-194. [CrossRef]

53. Lees, C.; Hopkins, J. Effect of aerobic exercise on cognition, academic achievement, and psychosocial function in children: A systematic review of randomized control trials. Prev. Chronic Dis. 2013, 10. [CrossRef]

54. Mullender-Wijnsma, M.J.; Hartman, E.; de Greeff, J.W.; Doolaard, S.; Bosker, R.J.; Visscher, C. Physically Active Math and Language Lessons Improve Academic Achievement: A Cluster Randomized Controlled Trial. Pediatrics 2016, 137, e20152743. [CrossRef]

55. Sibley, B.A.; Etnier, J.L. The relationship between physical activity and cognition in children: A meta-analysis. Pediatr. Exerc. Sci. 2003, 15, 243-256. [CrossRef]

56. Voss, M.W.; Chaddock, L.; Kim, J.S.; VanPatter, M.; Pontifex, M.B.; Raine, L.B.; Cohen, N.J.; Hillman, C.H.; Kramer, A.F. Aerobic fitness is associated with greater efficiency of the network underlying cognitive control in preadolescent children. Neuroscience 2011, 199, 166-176. [CrossRef] [PubMed]

57. Tarp, J.; Domazet, S.S.L.; Froberg, K.; Hillman, C.H.; Andersen, L.L.B.L.; Bugge, A.; Trudeau, F.; Shephard, R.; Fedewa, A.; Ahn, S.; et al. Effectiveness of a School-Based Physical Activity Intervention on Cognitive Performance in Danish Adolescents: LCoMotion—Learning, Cognition and Motion-A Cluster Randomized Controlled Trial. PLoS ONE 2016, 11, e0158087. [CrossRef] [PubMed]

58. Gapin, J.I.; Labban, J.D.; Etnier, J.L. The effects of physical activity on attention deficit hyperactivity disorder symptoms: The evidence. Prev. Med. 2011, 52, 70-74. [CrossRef]

59. Gapin, J.; Etnier, J.L. The Relationship between Physical Activity and Executive Function Performance in Children with Attention-Deficit Hyperactivity Disorder. J. Sport Exerc. Psychol. 2010, 32, 753-763. [CrossRef]

60. Resaland, G.K.; Aadland, E.; Moe, V.F.; Aadland, K.N.; Skrede, T.; Stavnsbo, M.; Suominen, L.; Steene-Johannessen, J.; Glosvik, Ø.; Andersen, J.R.; et al. Effects of physical activity on schoolchildren's academic performance: The Active Smarter Kids (ASK) cluster-randomized controlled trial. Prev. Med. 2016, 91, 322-328. [CrossRef]

61. Krafft, C.E.; Pierce, J.E.; Schwarz, N.F.; Chi, L.; Weinberger, A.L.; Schaeffer, D.J.; Rodrigue, A.L.; Camchong, J.; Allison, J.D.; Yanasak, N.E.; et al. An eight months randomized controlled exercise intervention alters resting state synchrony in overweight children. Neuroscience 2014, 256, 445-455. [CrossRef]

62. Krafft, C.E.; Schwarz, N.F.; Chi, L.; Weinberger, A.L.; Schaeffer, D.J.; Pierce, J.E.; Rodrigue, A.L.; Yanasak, N.E.; Miller, P.H.; Tomporowski, P.D.; et al. An 8-month randomized controlled exercise trial alters brain activation during cognitive tasks in overweight children. Obesity 2014, 22, 232-242. [CrossRef]

63. Davis, C.; Tomporowski, P.; McDowell, J.; Austin, B.; Miller, P.; Yanasak, N.; Allison, J.; Naglieri, J. Exercise improves executive function and achievement and alters brain activation in overweight children: A randomized controlled trial. Heal. Psychol. 2011, 30, 91-98. [CrossRef]

64. Carson, V.; Tremblay, M.S.; Chaput, J.; Chastin, S.F.M. Associations between sleep duration, sedentary time, physical activity, and health indicators among Canadian children and youth using compositional analyses 1. Appl. Physiol. Nutr. Metab. 2016, 302, 294-302. [CrossRef]

65. Koutsandreou, F.; Wegner, M.; Niemann, C.; Budde, H. Effects of Motor versus Cardiovascular Exercise Training on Children's Working Memory. Med. Sci. Sports Exerc. 2016, 47, 1144-1152. [CrossRef] [PubMed]

66. Haapala, E.A.; Lintu, N.; Väistö, J.; Robinson, L.E.; Viitasalo, A.; Lindi, V.; Lakka, T. Associations of Cardiovascular Fitness, Motor Performance and Adiposity with Cognition in Children. Med. Sci. Sports Exerc. 2015. [CrossRef] [PubMed] 
67. Haapala, E.; Lintu, N.; Vaisto, J.; Robinson, L.; Viitasalo, A.; Lindi, V.; Lakka, T. Associations of physical performance and adiposity with cognition in children. Med. Sci. Sports Exerc. 2015, 47, 2166-2174. [CrossRef] [PubMed]

68. Gomez-Pinilla, F. The combined effects of exercise and foods in preventing neurological and cognitive disorders. Prev. Med. 2011, 52, S75-S80. [CrossRef]

69. Sedentary Behaviour Research Network Letter to the Editor: Standardized use of the terms "sedentary" and "sedentary behaviours". Appl. Physiol. Nutr. Metab. 2012, 37, 540-542. [CrossRef]

70. Carson, V.; Kuzik, N.; Hunter, S.; Wiebe, S.A.; Spence, J.C.; Friedman, A.; Tremblay, M.S.; Slater, L.G.; Hinkley, T. Systematic review of sedentary behavior and cognitive development in early childhood. Prev. Med. 2015, 78, 115-122. [CrossRef]

71. Carson, V.; Hunter, S.; Kuzik, N.; Gray, C.E.; Poitras, V.J.; Chaput, J.P.; Saunders, T.J.; Katzmarzyk, P.T.; Okely, A.D.; Connor Gorber, S.; et al. Systematic review of sedentary behaviour and health indicators in school-aged children and youth: An update. Appl. Physiol. Nutr. Metab. 2016, 41, 240-265. [CrossRef]

72. Wolf, C.; Wolf, S.; Weiss, M.; Nino, G. Children's Environmental Health in the Digital Era: Understanding Early Screen Exposure as a Preventable Risk Factor for Obesity and Sleep Disorders. Children 2018, 5, 31. [CrossRef]

73. Haapala, E.A.; Poikkeus, A.-M.; Kukkonen-Harjula, K.; Tompuri, T.; Lintu, N.; Väistö, J.; Leppänen, P.H.T.; Laaksonen, D.E.; Lindi, V.; Lakka, T. Associations of Physical Activity and Sedentary Behavior with Academic Skills - A Follow-up Study among Primary School Children. PLoS ONE 2014, 10, e107031. [CrossRef]

74. Haapala, E.A.; Väistö, J.; Lintu, N.; Westgate, K.; Ekelund, U.; Poikkeus, A.-M.; Brage, S.; Lakka, T.A. Physical activity and sedentary time in relation to academic achievement in children. J. Sci. Med. Sport 2016, 1-6. [CrossRef]

75. Hobbs, M.; Pearson, N.; Foster, P.J.; Biddle, S.J.H. Sedentary behaviour and diet across the lifespan: An update systematic review. Br. J. Sports Med. 2014, 49, 1179-1188. [CrossRef] [PubMed]

76. Eloranta, A.M.; Schwab, U.; Venäläinen, T.; Kiiskinen, S.; Lakka, H.M. Nutrition, Metabolism \& Cardiovascular Diseases Dietary quality indices in relation to cardiometabolic risk among Finnish children aged 6 e 8 years e The PANIC study. Nutr. Metab. Cardiovasc. Dis. 2016, 26, 1-9.

77. Eloranta, A.-M.; Lindi, V.; Schwab, U.; Tompuri, T.; Kiiskinen, S.; Lakka, H.-M.; Laitinen, T.; Lakka, T. A Dietary factors associated with overweight and body adiposity in Finnish children aged 6-8 years: The PANIC Study. Int. J. Obes. 2012, 36, 950-955. [CrossRef] [PubMed]

78. Veena, S.R.; Hegde, B.G.; Ramachandraiah, S.; Krishnaveni, G.V.; Fall, C.H.D.; Srinivasan, K. Relationship between adiposity and cognitive performance in 9-10-year-old children in South India. Arch. Dis. Child. 2014, 99, 126-134. [CrossRef] [PubMed]

79. Kamijo, K.; Pontifex, M.B.; Khan, N.; Raine, L.B.; Scudder, M.R.; Drollette, E.S.; Evans, E.M.; Castelli, D.M.; Hillman, C.H. The negative association of childhood obesity to cognitive control of action monitoring. Cereb. Cortex 2014, 24, 654-662. [CrossRef]

80. Kamijo, K.; Pontifex, M.B.; Khan, N.; Raine, L.B.; Scudder, M.R.; Drollette, E.S.; Evans, E.M.; Castelli, D.M.; Hillman, C.H. The association of childhood obesity to neuroelectric indices of inhibition. Psychophysiology 2012, 49, 1361-1371. [CrossRef] [PubMed]

81. Esteban-Cornejo, I.; Tejero-González, C.M.; Castro-Piñero, J.; Conde-Caveda, J.; Cabanas-Sanchez, V.; Sallis, J.F.; Veiga, Ó.L. Independent and combined influence of neonatal and current body composition on academic performance in youth: The UP \& DOWN Study. Pediatr. Obes. 2015, 10, 157-164.

82. Kamijo, K.; Khan, N.; Pontifex, M.B.; Scudder, M.R.; Drollette, E.S.; Raine, L.B.; Evans, E.M.; Castelli, D.M.; Hillman, C.H. The relation of adiposity to cognitive control and scholastic achievement in preadolescent children. Obesity 2012, 20, 2406-2411. [CrossRef]

83. Kanoski, S.E.; Davidson, T.L. Western diet consumption and cognitive impairment: Links to hippocampal dysfunction and obesity. Physiol. Behav. 2011, 103, 59-68. [CrossRef]

84. Yau, P.L.; Javier, D.C.; Ryan, C.M.; Tsui, W.H.; Ardekani, B.A.; Ten, S.; Convit, a. Preliminary evidence for brain complications in obese adolescents with type 2 diabetes mellitus. Diabetologia 2010, 53, 2298-2306. [CrossRef]

85. Yau, P.L.; Kang, E.H.; Javier, D.C.; Convit, A. Preliminary evidence of cognitive and brain abnormalities in uncomplicated adolescent obesity. Obesity 2014, 22, 1865-1871. [CrossRef] [PubMed] 
86. Scudder, M.R.; Khan, N.A.; Lambourne, K.; Drollette, E.S.; Herrmann, S.D.; Betts, J.L.; Washburn, R.A.; Donnelly, J.E.; Hillman, C.H.; Cognitive, A. Cognitive Control in Preadolescent Children with Risk Factors for Metabolic Syndrome. Heal. Psychol. 2015, 34, 243-252. [CrossRef] [PubMed]

87. Esteban-Cornejo, I.; Martinez-Gomez, D.; Gómez-Martínez, S.; del Campo-Vecino, J.; Fernández-Santos, J.; Castro-Piñero, J.; Marcos, A.; Veiga, O.L. Inflammatory biomarkers and academic performance in youth. The UP\& DOWN Study. Brain. Behav. Immun. 2016, 5, 1-6.

88. Anderson, Y.C.; Kirkpatrick, K.; Dolan, G.M.S.; Wouldes, T.A.; Grant, C.C.; Cave, T.L.; Wild, C.E.K.; Derraik, J.G.B.; Cutfield, W.S.; Hofman, P.L. Do changes in weight status affect cognitive function in children and adolescents with obesity? A secondary analysis of a clinical trial. BMJ Open 2019, 9. [CrossRef]

89. Cserjési, R.; Molnár, D.; Luminet, O.; Lénárd, L. Is there any relationship between obesity and mental flexibility in children? Appetite 2007, 49, 675-678. [CrossRef]

90. Borkertienè, V.; Stasiulis, A.; Zacharienè, B.; Kyguolienè, L.; Bacevičienè, R. Association among executive function, physical activity, and weight status in youth. Medicina 2019, 55, 677. [CrossRef]

91. Martin, A.; Booth, J.N.; McGeown, S.; Niven, A.; Sproule, J.; Saunders, D.H.; Reilly, J.J. Longitudinal Associations Between Childhood Obesity and Academic Achievement: Systematic Review with Focus Group Data. Curr. Obes. Rep. 2017, 6, 297-313. [CrossRef]

92. Afzal, A.S.; Gortmaker, S. The relationship between obesity and cognitive performance in children: A longitudinal study. Child. Obes. 2015, 11, 466-474. [CrossRef]

93. Kopasz, M.; Loessl, B.; Hornyak, M.; Riemann, D.; Nissen, C.; Piosczyk, H.; Voderholzer, U. Sleep and memory in healthy children and adolescents-A critical review. Sleep Med. Rev. 2010, 14, 167-177. [CrossRef]

94. Dewald, J.F.; Meijer, A.M.; Oort, F.J.; Kerkhof, G.A.; Bögels, S.M. The influence of sleep quality, sleep duration and sleepiness on school performance in children and adolescents: A meta-analytic review. Sleep Med. Rev. 2010, 14, 179-189. [CrossRef]

95. Buckhalt, J.A.; El-Sheikh, M.; Keller, P. Children's sleep and cognitive functioning: Race and socioeconomic status as moderators of effects. Child. Dev. 2007, 78, 213-231. [CrossRef] [PubMed]

96. Sadeh, A.; Gruber, R.; Raviv, A. The Effects of Sleep Restriction and Extension on School-Age Children: What a Difference an Hour Makes. Child. Dev. 2003, 74, 444-455. [CrossRef] [PubMed]

97. De Bruin, E.J.; van Run, C.; Staaks, J.; Meijer, A.M. Effects of sleep manipulation on cognitive functioning of adolescents: A systematic review. Sleep Med. Rev. 2017, 32, 45-57. [CrossRef] [PubMed]

98. Santisteban, J.A.; Brown, T.G.; Ouimet, M.C.; Gruber, R. Cumulative mild partial sleep deprivation negatively impacts working memory capacity but not sustained attention, response inhibition, or decision making: A randomized controlled trial. Sleep Health 2019, 5, 101-108. [CrossRef] [PubMed]

99. Lo, J.C.; Ong, J.L.; Leong, R.L.F.; Gooley, J.J.; Chee, M.W.L. Cognitive Performance, Sleepiness, and Mood in Partially Sleep Deprived Adolescents: The Need for Sleep Study. Sleep 2016, 39, 687-698. [CrossRef] [PubMed]

100. Vriend, J.L.; Davidson, F.D.; Corkum, P.V.; Rusak, B.; Chambers, C.T.; McLaughlin, E.N. Manipulating Sleep Duration Alters Emotional Functioning and Cognitive Performance in Children. J. Pediatr. Psychol. 2013, 38, 1058-1069. [CrossRef] [PubMed]

101. Astill, R.G.; Van der Heijden, K.B.; Van IJzendoorn, M.H.; Van Someren, E.J.W. Sleep, cognition, and behavioral problems in school-age children: A century of research meta-analyzed. Psychol. Bull. 2012, 138, 1109-1138. [CrossRef]

102. Touchette, É.; Petit, D.; Séguin, J.R.; Boivin, M.; Tremblay, R.E.; Montplaisir, J.Y. Associations Between Sleep Duration Patterns and Behavioral/Cognitive Functioning at School Entry. Sleep 2007, 30, 1213-1219. [CrossRef]

103. Chuah, Y.M.L.; Venkatraman, V.; Dinges, D.F.; Chee, M.W.L. The Neural Basis of Interindividual Variability in Inhibitory Efficiency after Sleep Deprivation. J. Neurosci. 2006, 26, 7156-7162. [CrossRef]

104. Drummond, S.P.A.; Paulus, M.P.; Tapert, S.F. Effects of two nights sleep deprivation and two nights recovery sleep on response inhibition. J. Sleep Res. 2006, 15, 261-265. [CrossRef]

105. Molfese, D.L.; Ivanenko, A.; Key, A.F.; Roman, A.; Molfese, V.J.; O’Brien, L.M.; Gozal, D.; Kota, S.; Hudac, C.M. A One-Hour Sleep Restriction Impacts Brain Processing in Young Children across Tasks: Evidence from Event-Related Potentials. Dev. Neuropsychol. 2013, 38, 317-336. [CrossRef] [PubMed] 
106. Dewald-Kaufmann, J.F.; Oort, F.J.; Meijer, A.M. The effects of sleep extension on sleep and cognitive performance in adolescents with chronic sleep reduction: An experimental study. Sleep Med. 2013, 14, 510-517. [CrossRef] [PubMed]

107. Randazzo, A.C.; Muehlbach, M.J.; Schweitzer, P.K.; Waish1, J.K. Cognitive Function Following Acute Sleep Restriction in Children Ages 10-14. Sleep 1998, 21, 861-868. [PubMed]

108. Fallone, G.; Acebo, C.; Arnedt, J.T.; Seifer, R.; Carskadon, M.A. Effects of Acute Sleep Restriction on Behavior, Sustained Attention, and Response Inhibition in Children. Percept. Mot. Skills 2001, 93, 213-229. [CrossRef] [PubMed]

109. Cappuccio, F.P.; Taggart, F.M.; Kandala, N.-B.; Currie, A.; Peile, E.; Stranges, S.; Miller, M.A. Meta-Analysis of Short Sleep Duration and Obesity in Children and Adults. Sleep 2008, 31, 619-626. [CrossRef]

110. Sperry, S.D.; Scully, I.D.; Gramzow, R.H.; Jorgensen, R.S. Sleep Duration and Waist Circumference in Adults: A Meta-Analysis. Sleep 2015, 38, 1269-1276. [CrossRef]

111. Fatima, Y.; Doi, S.A.R.; Mamun, A.A. Sleep quality and obesity in young subjects: A meta-analysis. Obes. Rev. 2016, 17, 1154-1166. [CrossRef]

112. Peltzer, K.; Pengpid, S. Sleep Duration, Sleep Quality, Body Mass Index, and Waist Circumference among Young Adults from 24 Low- and Middle-Income and Two High-Income Countries. Int. J. Environ. Res. Public Health 2017. [CrossRef]

113. Westerlund, L.; Ray, C.; Roos, E. Associations between sleeping habits and food consumption patterns among 10-11-year-old children in Finland. Br. J. Nutr. 2009, 102, 1531-1537. [CrossRef]

114. Mi, S.J.; Kelly, N.R.; Brychta, R.J.; Grammer, A.C.; Jaramillo, M.; Chen, K.Y.; Fletcher, L.A.; Bernstein, S.B.; Courville, A.B.; Shank, L.M.; et al. Associations of sleep patterns with metabolic syndrome indices, body composition, and energy intake in children and adolescents. Pediatr. Obes. 2019, 14, e12507. [CrossRef]

115. Weiss, A.; Xu, F.; Storfer-Isser, A.; Thomas, A.; Ievers-Landis, C.E.; Redline, S. The Association of Sleep Duration with Adolescents' Fat and Carbohydrate Consumption. Sleep 2010, 33, 1201-1209. [CrossRef] [PubMed]

116. Knutson, K.L. Does inadequate sleep play a role in vulnerability to obesity? Am. J. Hum. Biol. 2012, 24, 361-371. [CrossRef] [PubMed]

117. Rolls, E.T. Reward Systems in the Brain and Nutrition. Annu. Rev. Nutr. 2016, 36, 435-470. [CrossRef]

118. Jiao, J.; Li, Q.; Chu, J.; Zeng, W.; Yang, M.; Zhu, S. Effect of n-3 PUFA supplementation on cognitive function throughout the life span from infancy to old age: A systematic review and meta-analysis of randomized controlled trials. Am. J. Clin. Nutr. 2014, 100, 1422-1436. [CrossRef] [PubMed]

119. Baym, C.L.; Khan, N.A.; Monti, J.M.; Raine, L.B.; Drollette, E.S.; Moore, R.D.; Scudder, M.R.; Kramer, A.F.; Hillman, C.H.; Cohen, N.J. Dietary lipids are differentially associated with hippocampal-dependent relational memory in prepubescent children. Am. J. Clin. Nutr. 2014, 99, 1026-1032. [CrossRef] [PubMed]

120. Zhang, J.; Hebert, J.; Muldoon, M. Dietary fat intake is associated with psychosocial and cognitive functioning of school-aged children in the United States. J. Nutr. 2005, 135, 1967-1973. [CrossRef]

121. Lassek, W.D.; Gaulin, S.J.C. Sex differences in the relationship of dietary fatty acids to cognitive measures in American children. Front. Evol. Neurosci. 2011, 3, 1-8. [CrossRef]

122. Boucher, O.; Burden, M.J.; Muckle, G.; Saint-amour, D.; Ayotte, P.; Dewailly, E.; Nelson, C.A.; Jacobson, S.W.; Jacobson, J.L. Neurophysiologic and neurobehavioral evidence of beneficial effects of prenatal omega-3 fatty acid intake on memory function at school age 1-3. Am. J. Clin. Nutr. 2011, 93, 1025-1037. [CrossRef]

123. Montgomery, P.; Burton, J.R.; Sewell, R.P.; Spreckelsen, T.F.; Richardson, A.J. Low Blood Long Chain Omega-3 Fatty Acids in UK Children Are Associated with Poor Cognitive Performance and Behavior: A Cross-Sectional Analysis from the DOLAB Study. PLoS ONE 2013, 8, e66697. [CrossRef]

124. Haapala, E.; Viitasalo, A.; Venäläinen, T.; Eloranta, A.-M.; Ågren, J.; Lindi, V.; Lakka, T. Plasma polyunsaturated fatty acids are directly associated with cognition in overweight children but not in normal weight children. Acta Paediatr. 2016, 12, 1-6. [CrossRef]

125. Sørensen, L.B.; Damsgaard, C.T.; Dalskov, S.-M.; Petersen, R.A.; Egelund, N.; Dyssegaard, C.B.; Stark, K.D.; Andersen, R.; Tetens, I.; Astrup, A.; et al. Diet-induced changes in iron and n-3 fatty acid status and associations with cognitive performance in 8-11-year-old Danish children: Secondary analyses of the Optimal Well-Being, Development and Health for Danish Children through a Healthy New Nordic Diet. Br. J. Nutr. 2015, 114, 1623-1637. [CrossRef] 
126. Rask-Nissilä, L.; Jokinen, E.; Terho, P.; Tammi, A.; Lapinleimu, H.; Rönnemaa, T.; Viikari, J.; Seppänen, R.; Korhonen, T.; Tuominen, J.; et al. Neurological development of 5-year-old children receiving a low-saturated fat, low-cholesterol diet since infancy: A randomized controlled trial. JAMA 2000, 284, 993-1000. [CrossRef]

127. Innis, S.M. Dietary omega 3 fatty acids and the developing brain. Brain Res. 2008, 1237, 35-43. [CrossRef]

128. Khan, N.A.; Raine, L.B.; Drollette, E.S.; Scudder, M.R.; Kramer, A.F.; Hillman, C.H. Dietary fiber is positively associated with cognitive control among prepubertal children. J. Nutr. 2015, 145, 143-149. [CrossRef] [PubMed]

129. Johnson, M.; Fransson, G.; Östlund, S.; Areskoug, B.; Gillberg, C. Omega 3/6 fatty acids for reading in children: A randomized, double-blind, placebo-controlled trial in 9-year-old mainstream schoolchildren in Sweden. J. Child. Psychol. Psychiatry 2017, 58, 83-93. [CrossRef] [PubMed]

130. Funari, V.A.; Crandall, J.E.; Tolan, D.R. Fructose metabolism in the cerebellum. Cerebellum 2007, 6, $130-140$. [CrossRef] [PubMed]

131. Cisternas, P.; Salazar, P.; Serrano, F.G.; Montecinos-Oliva, C.; Arredondo, S.B.; Varela-Nallar, L.; Barja, S.; Vio, C.P.; Gomez-Pinilla, F.; Inestrosa, N.C. Fructose consumption reduces hippocampal synaptic plasticity underlying cognitive performance. Biochim. Biophys. Acta Mol. Basis Dis. 2015, 1852, 2379-2390. [CrossRef]

132. Gomez-Pinilla, F.; Hillman, C. The Influence of Exercise on Cognitive Abilities. Compr. Physiol. 2013, 3, 403-428.

133. Simopoulos, A.P. Dietary omega-3 fatty acid deficiency and high fructose intake in the development of metabolic syndrome brain, metabolic abnormalities, and non-alcoholic fatty liver disease. Nutrients 2013, 5, 2901-2923. [CrossRef]

134. Calvo-Ochoa, E.; Hernández-Ortega, K.; Ferrera, P.; Morimoto, S.; Arias, C. Short-term high-fat-and-fructose feeding produces insulin signaling alterations accompanied by neurite and synaptic reduction and astroglial activation in the rat hippocampus. J. Cereb. Blood Flow Metab. 2014, 34, 1001-1008. [CrossRef]

135. Cao, D.; Lu, H.; Lewis, T.L.; Li, N. Intake of sucrose-sweetened water induces insulin resistance and exacerbates memory deficits and amyloidosis in a transgenic mouse model of Alzheimer disease. J. Biol. Chem. 2007, 282, 36275-36282. [CrossRef] [PubMed]

136. Young, H.; Benton, D. The effect of using isomaltulose to modulate the glycaemic properties of breakfast on the cognitive performance of children. Eur. J. Nutr. 2014, 54, 1013-1020. [CrossRef] [PubMed]

137. Isaacs, E.B.; Gadian, D.G.; Sabatini, S.; Chong, W.K.; Quinn, B.T.; Fischl, B.R.; Lucas, A. The Effect of Early Human Diet on Caudate Volumes and IQ. Pediatr. Res. 2008, 63, 308-314. [CrossRef] [PubMed]

138. Frisardi, V.; Panza, F.; Seripa, D.; Inbimbo, B.; Vendemiale, G. Nutraceutical properties of Mediterranean diet and cognitive decline: Possible underlying mechanisms. J. Alzheimer's Dis. 2010, 22, 715-740. [CrossRef] [PubMed]

139. Shi, Z.; El-Obeid, T.; Li, M.; Xu, X.; Liu, J. Iron-related dietary pattern increases the risk of poor cognition. Nutr. J. 2019, 18, 48. [CrossRef]

140. Lam, L.F.; Lawlis, T.R. Feeding the brain-The effects of micronutrient interventions on cognitive performance among school-aged children: A systematic review of randomized controlled trials. Clin. Nutr. 2017, 36, 1007-1014. [CrossRef]

141. Burkhalter, T.M.; Hillman, C.H. Forum on Child Obesity Interventions A Narrative Review of Physical Activity, Nutrition, and Obesity to Cognition and Scholastic Performance across the Human Lifespan 1-3. Adv. Nutr. 2011, 2, 201S-206S. [CrossRef]

142. Taras, H. Nutrition and student performance at school. J. Sch. Health 2005, 75, 199-213. [CrossRef]

143. Haapala, E.A.; Eloranta, A.-M.; Venäläinen, T.; Schwab, U.; Lindi, V.; Lakka, T.A. Associations of diet quality with cognition in children-the Physical Activity and Nutrition in Children Study. Br. J. Nutr. 2015, 114, 1080-1087. [CrossRef]

144. Burrows, T.; Goldman, S.; Pursey, K.; Lim, R. Is there an association between dietary intake and academic achievement: A systematic review. J. Hum. Nutr. Diet 2017, 30, 117-140. [CrossRef]

145. Åberg, M.A.I.; Åberg, N.; Brisman, J.; Sundberg, R.; Winkvist, A.; Torén, K. Fish intake of Swedish male adolescents is a predictor of cognitive performance. Acta Paediatr. Int. J. Paediatr. 2009, 98, 555-560. [CrossRef] [PubMed]

146. Stea, T.H.; Torstveit, M.K. Association of lifestyle habits and academic achievement in Norwegian adolescents: A cross-sectional study. BMC Public Health 2014, 14, 829. [CrossRef] 
147. Florence, M.; Asbridge, M.; Veugelers, P. Diet Quality and Academic Performance. J. Sch. Health 2008, 78, 239-241. [CrossRef]

148. Tangney, C.C.; Scarmeas, N. The good, bad, and ugly? How blood nutrient concentrations may reflect cognitive performance. Neurology 2012, 78, 230-231. [CrossRef] [PubMed]

149. Vassiloudis, I.; Yiannakouris, N. Academic Performance in Relation to Adherence to the Mediterranean Diet and Energy Balance Behaviors in Greek Primary Schoolchildren. J. Nutr. Educ. Behav. 2014, 46, 164-170. [CrossRef] [PubMed]

150. Esteban-Cornejo, I.; Izquierdo-Gomez, R.; Gómez-Martínez, S.; Padilla-Moledo, C.; Castro-Piñero, J.; Marcos, A.; Veiga, O.L. Adherence to the Mediterranean diet and academic performance in youth: The UP\& DOWN study. Eur. J. Nutr. 2015, 55, 1133-1140.

151. Haapala, E.A.; Eloranta, A.-M.; Venäläinen, T.; Jalkanen, H.; Poikkeus, A.-M.; Ahonen, T.; Lindi, V.; Lakka, T. Diet quality and academic achievement-A prospective study among primary school children. Eur. J. Nutr. 2017, 56, 2299-2308.

152. Sørensen, L.B.; Dyssegaard, C.B.; Damsgaard, C.T.; Petersen, R.A.; Dalskov, S.-M.; Hjorth, M.F.; Andersen, R.; Tetens, I.; Ritz, C.; Astrup, A.; et al. The effects of Nordic school meals on concentration and school performance in 8- to 11-year-old children in the OPUS School Meal Study: A cluster-randomised, controlled, cross-over trial. Br. J. Nutr. 2015, 113, 1280-1291. [CrossRef]

153. Sørensen, L.B.; Damsgaard, C.T.; Petersen, R.A.; Dalskov, S.-M.; Hjorth, M.F.; Dyssegaard, C.B.; Egelund, N.; Tetens, I.; Astrup, A.; Lauritzen, L.; et al. Differences in the effects of school meals on children's cognitive performance according to gender, household education and baseline reading skills. Eur. J. Clin. Nutr. 2016, 70, 1-7. [CrossRef]

154. Gale, C.; Martyn, C.; Marriot, L.; Limond, J.; Crozier, S.; Inskip, H.; Godfrey, K.; Law, C.; Cooper, C.; Robinson, S.; et al. Dietary patterns in infancy and cognitive and neuropsychological function in childhood. J. Child. Psychol. Psychiatry 2009, 50, 816-823. [CrossRef]

155. Feinstein, L.; Sabates, R.; Sorhaindo, A.; Rogers, I.; Herrick, D.; Northstone, K.; Emmett, P. Dietary patterns related to attainment in school: The importance of early eating patterns. J. Epidemiol. Community Health 2008, 62, 734-739. [CrossRef]

156. Nyaradi, A.; Foster, J.K.; Hickling, S.; Li, J.; Ambrosini, G.L.; Jacques, A.; Oddy, W.H. Prospective associations between dietary patterns and cognitive performance during adolescence. J. Child. Psychol. Psychiatry 2014, 55, 1017-1024. [CrossRef]

157. Hillman, C.H.; Erickson, K.I.; Kramer, A.F. Be smart, exercise your heart: Exercise effects on brain and cognition. Nat. Rev. Neurosci. 2008, 9, 58-65. [CrossRef]

158. Singh, A.; Uijtdewilligen, L.; Twisk, J.W.R.; Van Mechelen, W.; Chinapaw, M.J.M. Physical activity and performance at school: A systematic review of the literature including a methodological quality assessment. Arch. Pediatr. Adolesc. Med. 2012, 166, 49-55. [CrossRef]

159. Van Dijk, M.L.; de Groot, R.H.M.; Savelberg, H.H.C.M.; van Acker, F.; Kirschner, P.A. The association between objectively measured physical activity and academic achievement in dutch adolescents: Findings from the GOALS study. J. Sport Exerc. Psychol. 2014, 36, 460-473. [CrossRef]

160. Ardoy, D.N.; Fernández-Rodríguez, J.M.; Jiménez-Pavón, D.; Castillo, R.; Ruiz, J.R.; Ortega, F.B. A Physical Education trial improves adolescents' cognitive performance and academic achievement: The EDUFIT study. Scand. J. Med. Sci. Sport. 2014, 24, e52-e61. [CrossRef]

161. Wittberg, R.A.; Northrup, K.L.; Cottrell, L.A. Children's aerobic fitness and academic achievement: A longitudinal examination of students during their fifth and seventh grade years. Am. J. Public Health 2012, 102, 2303-2307. [CrossRef]

162. London, R.A.; Castrechini, S. A longitudinal examination of the link between youth physical fitness and academic achievement. J. Sch. Health 2011, 81, 400-408. [CrossRef]

163. Sardinha, L.B.; Marques, A.; Minderico, C.; Palmeira, A.; Martins, S.; Santos, D.A.; Ekelund, U. Longitudinal relationship between cardiorespiratory fitness and academic achievement. Med. Sci. Sports Exerc. 2016, 48, 839-844. [CrossRef] 
164. Bazinet, R.P.; Layé, S. Polyunsaturated fatty acids and their metabolites in brain function and disease. Nat. Rev. Neurosci. 2014, 15, 771-785. [CrossRef]

165. Francis, H.; Stevenson, R. The longer-term impacts of Western diet on human cognition and the brain. Appetite 2013, 63, 119-128. [CrossRef]

(C) 2020 by the authors. Licensee MDPI, Basel, Switzerland. This article is an open access article distributed under the terms and conditions of the Creative Commons Attribution (CC BY) license (http://creativecommons.org/licenses/by/4.0/). 